\title{
Speech transcript stokes opposition to Harvard head
}

\section{Emily Singer, Boston}

The president of Harvard University is under growing pressure, following the release of a full transcript of contentious remarks he made last month about women in science.

Some faculty were considering calling for a vote of no confidence in Larry Summers at a special meeting of the Faculty of Arts and Sciences due to take place on 22 February, although there are indications that such a vote may not take place until next month.

National controversy continues to rage over Summers' comments, in which he suggested that differences in "intrinsic aptitude" might be a key factor behind the scarcity of women in science, outweighing the impact of gender discrimination.

The Harvard Corporation, the board to which Summers is answerable, took the highly unusual step of issuing a statement of support for him. "We are confident of his ability to work constructively with the faculty and others," the 17 February statement said.

The same day, Harvard released a 7,000-word transcript of Summers' speech and the questions that followed it. In the transcript, Summers compared the under-representation of women in science to that of whites in the National Basketball League and Jews in farming.

Summers' position was damaged by a stormy, closed-faculty meeting on $\mathbf{1 5}$ February, at which many criticized what they see as his autocratic management style (see Nature 433, 190-192; 2005).

Some critics say that the release of the transcript has weakened his position. "My sense is that Larry Summers' job is on the line," says Everett Mendelsohn, a historian of science at Harvard.

"He has only a few options," says Arthur Kleinman, chairman of the anthropology department. "Resign, get fired, or rework his policy style." Fellow economists, however, have circulated a letter of support for Summers, which by 21 February had attracted 180 signatures.

And even some critics of his remarks on women say he should stay. In her research, Harvard psychologist Elizabeth Spelke has found no evidence of a biological basis for gender differences in mathematical ability. "I disagree with almost everything Summers said," says Spelke. "But I hope he will keep his job and rectify the situation, in the way he said he would." Summers has repeatedly apologized for his remarks.

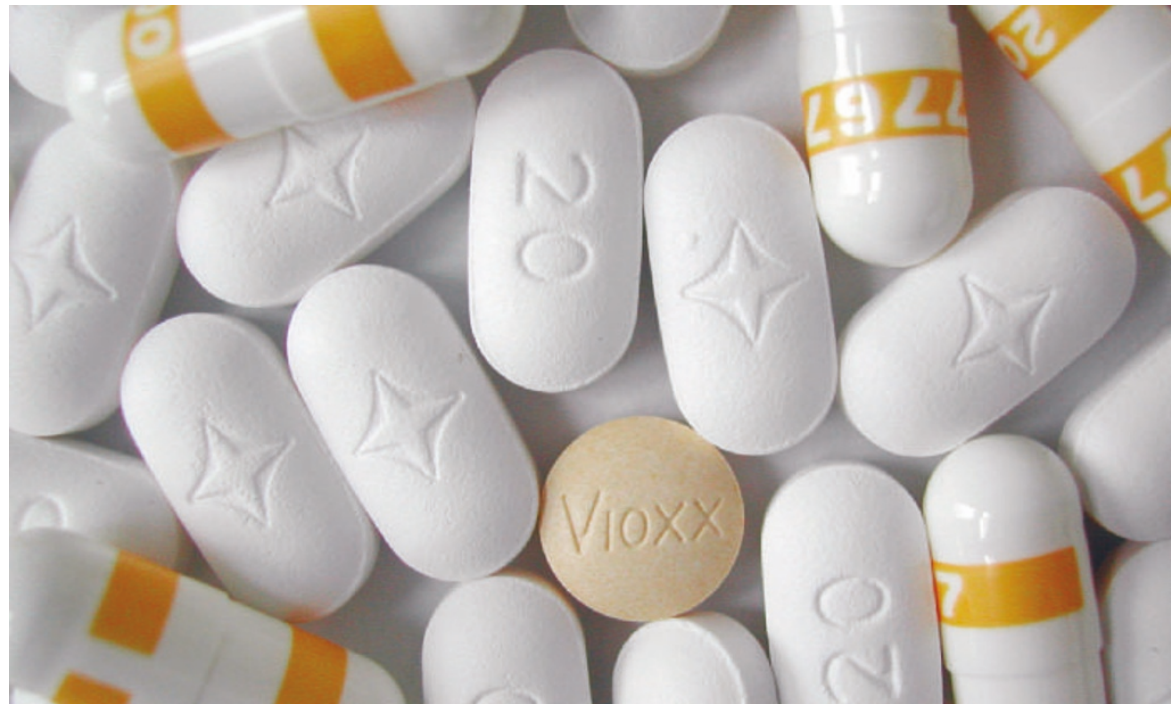

Pill for all ills: painkillers such as Vioxx increase patients' risk of stroke but are unlikely to be banned.

\section{Vioxx may go back on sale after scraping past FDA panel}

Meredith Wadman, Washington

Advisers to the US Food and Drug Administration (FDA) have voted, by a narrow margin, that it should not ban Vioxx - the painkiller withdrawn by drug-maker Merck.

They also said that Pfizer's Celebrex and Bextra, two other members of the family of painkillers known as COX-2 inhibitors, should remain available, despite the fact that they too boost patients' risk of heart attack and stroke.

The recommendations of the arthritis and drug safety advisory panel offer some measure of relief to the pharmaceutical industry, which has faced a barrage of criticism for its promotion of the painkillers. But the advice of the panel, which met near Washington DC over 16-18 February, comes with several strings attached.

For example, most panel members said that manufacturers should be required to add a prominent warning about the drugs' risks to their labels; to stop direct-to-consumer advertising of the drugs; and to include detailed, written risk information with each prescription. The panel also unanimously stated that all three painkillers "significantly increase the risk of cardiovascular events".

The panel voted 17 to 15 against banning Vioxx (rofecoxib) entirely; the vote on Bextra (valdecoxib) was 17 to 13 with 2 abstentions; Celebrex (celecoxib) was endorsed 31 to 1. Shares of Merck, based in Whitehouse Station, New Jersey, and New York-based Pfizer closed up 13\% and 7\% respectively on 18 February, the day of the votes.

The FDA is expected to act on the recommendations within weeks. Although the agency usually follows the recommendations of its outside advisers, it is not bound to do so. A top official said that, in light of the closeness of some of the votes, the agency will examine the panel members' comments in detail before deciding what to do.

An official from Merck said during the meeting that it would consider reintroducing Vioxx, which it withdrew in September 2004. Pfizer's two painkillers are still on the market.

Throughout the three-day meeting, panelists struggled to reach a decision that balanced benefits with undeniable risks. They complained of a dearth of comprehensive clinical data on the cardiovascular risks of the drugs, and a similar lack for conventional non-steroidal anti-inflammatory inhibitors. Many physicians will now fall back on the latter for treating arthritis, despite the fact that they can cause gastric bleeding.

Alastair Wood of Vanderbilt University Medical Center in Nashville, Tennessee, the panel chairman, noted that the committee was dealing with "a much bigger safety problem" than existed for any of the drugs the FDA has withdrawn in the past. Robert Temple, acting director of an FDA Office of Drug Evaluation, said that the kind of study needed to address safety questions on the painkillers "is mind-bogglingly large", requiring perhaps 50,000 subjects.

The meeting capped a week of important developments at the FDA. On 14 February, President George W. Bush nominated Lester Crawford, acting head of the agency, as its permanent commissioner. The next day, the agency said it would create an advisory board to monitor and publicize safety problems in drugs already on the market.

But this Drug Safety Oversight Board will be dominated by FDA officials and will lack the power to ban drugs. "It's a cosmetic gesture," says David Graham, the physician in the agency's Office of Drug Safety whose highprofile Senate testimony last November first brought the agency under intense scrutiny. 